\title{
Third-person Perception and Its Predictors in the Age of Facebook
}

\author{
Assist. Lecturer Raluca BUTUROIU, PhD \\ College of Communication and Public Relations \\ National University of Political Studies and Public Administration, Bucharest, Romania \\ E-mail: raluca.buturoiu@comunicare.ro
}

\section{Assist. Lecturer Flavia DURACH, PhD}

College of Communication and Public Relations

National University of Political Studies and Public Administration, Bucharest, Romania

E-mail: flavia.durach@comunicare.ro

\section{Assist. Lecturer Georgiana UDREA, PhD}

College of Communication and Public Relations

National University of Political Studies and Public Administration, Bucharest, Romania

E-mail: georgiana.udrea@comunicare.ro

\section{Prof. Nicoleta CORBU, PhD}

College of Communication and Public Relations

National University of Political Studies and Public Administration, Bucharest, Romania E-mail: nicoleta.corbu@comunicare.ro

\begin{abstract}
Originally proposed by Davison (1983), the TPE hypothesis maintains that people who are exposed to general persuasive media messages believe that these messages have a greater impact on others (i.e., "the third persons") than on themselves. Although classic TPE studies have long focused on the traditional mass media, many studies show that this effect is also common with regards to newer media outlets. By means of a survey ( $N=688)$, this study seeks to explore (1) the link between TPE and new mediums of communication (i.e., Facebook) and (2) the predictors of the TPE in the age of social media. Main results show that young
\end{abstract}




\section{References}

1. Andsager, J.L., \& White, H.A. (2007). Self versus others: Media, messages, and the third-person effect. Mahwah, NJ: Lawrence Erlbaum.

2. Atwood, E. (1994). Illusions of media power: the third-person effect. Journalism \& Mass Communication Quarterly, 71(2), 269-281.

3. Baek, Y.M., Kim, E.M., \& Bae, Y. (2013). My privacy is okay, but theirs is endangered: why comparative optimism matters in online privacy concerns. Computers in Human Behavior, 31, 48-56.

4. Banning, S.A. (2006). Third-person effects on political participation. Journalism \& Mass Communication Quarterly, 83(4), 785-800.

5. Banning, S.A. (2001). Do you see what I see? Third-person effects on public communication through self-esteem, social stigma, and product use. Mass Communication and Society, 4, 127-147.

6. Brosius, H. \& Engel, D. (1996).The causes of third-person effects: Unrealistic optimism, impersonal impact, or generalized negative attitudes toward media influence? International Journal of Public Opinion Research, 8(2), 142-162.

7. Chapin, J.R. (2013). I Know You Are, but What Am I? Adolescents' Third-Person Perception Regarding Dating Violence. The Journal of Educational Research, 106(5), 393-398. 
8. Cohen, J., \& Davis, R. (1991). Third-person effects and the differential impact in negative political advertising. Journalism Quarterly, 68, 680-688.

9. Cohen, J., Mutz, D., Price, V., \& Gunther, A. C. (1988). Perceived impact of defamation: An experiment on third-person effects. Public Opinion Quarterly, 52(2), 161-173.

10. Davison, W.P. (1983). The third-person effect in communication. Public Opinion Quarterly, 47(1), 1-15.

11. Day, A. (2008). Out of the living room and into the voting booth: An analysis of corporate public affairs advertising under the third person effect. American Behavioral Scientist, 52(2), 243-260.

12. Duck, J.M., Terry, D.J., \& Hogg, M.A. (1998). Perceptions of a media campaign: The role of social identity and the changing intergroup context. Personality and Social Psychology Bulletin, 24, 3-16.

13. Duck, J.M., \& Mullin, B. (1995). The perceived impact of the mass media: Reconsidering the third-person effect. European Journal of Social Psychology, 25, 77-93.

14. Duck, J.M., Hogg, M.A. \& Terry, D.J. (1995). Me, us, and them: Political identification and the third person effect in the 1993 Australian federal election. European Journal of Social Psychology, 25, 195-215.

15. Eveland, W.P., Nathanson, A.I., Detenber, B.H., \& McLeod, D.M. (1999). Rethinking the social distance corollary: Perceived likelihood of exposure and the thirdperson perception. Communication Research, 26, 275-302.

16. Eveland, W.P., Jr., \& McLeod, D.M. (1999). The effect of social desirability on perceived media impact: Implications for third-person perceptions. International Journal of Public Opinion Research, 11, 315-333.

17. Festinger, L. (1954). A Theory of Social Comparison Processes. Human Relations, 7, 117-140.

18. Freedman, P., \& Goldstein, K. (1999). Measuring media exposure and the effects of negative campaign ads. American Journal of Political Science, 43, 1189-1208.

19. Gibbons, F.X. \& Buunk, B.P. (1999). Individual differences in social comparison: The development of a scale of social comparison orientation. Journal of Personality and Social Psychology, 76, 129-142.

20. Golan, G. (2002). Religiosity and the third-person effect. Journal of Media and Religion, 1(2), 105-120.

21. Golan, G.J. \& Day, A.G. (2008). The First-Person Effect and Its Behavioral Consequences: A New Trend in the Twenty-Five Year History of Third-Person Effect Research. Mass Communication and Society, 11(4), 539-556.

22. Golan, G.J., \& Banning, S.A. (2008). Exploring a link between the third-person effect and the theory of reasoned action: Beneficial ads and social expectations. American Behavioral Scientist, 52(2), 208-224.

23. Golan, G.J., Banning, S.A., \& Lundy, L. (2008). Likelihood to vote, candidate choice and the third-person effect: Behavioral implications of political advertising in the 2004 presidential election. American Behavioral Scientist, 52(2), 278-290. 
24. Gunther, A.C., \& Storey, D. (2003). The influence of presumed influence. Journal of Communication, 53, 199-215.

25. Gunther, A.C., \& Hwa, A.P. (1996). Public perceptions of television influence and opinions about censorship in Singapore. International Journal of Public Opinion Research, 8(3), 248-265.

26. Gunther, A.C. (1995). Overrating the X-rating: The third-person perception and support for censorship of pornography. Journal of Communication, 45(1), 27-38.

27. Gunther, A.C., \& Mundy, P. (1993). Biased optimism and the third-person effect. Journalism Quarterly, 70(1), 58-67.

28. Gunther, A.C., \& Thorson, E. (1992). Perceived persuasive effects of commercials and public service announcements: The third-person effect in new domains. Communication Research, 19, 574-596.

29. Helweg-Larsen, M., \& Shepperd, J.A. (2001). Do moderators of the optimistic bias affect personal or target risk estimates? A review of the literature. Personality and Social Psychology Review, 5, 74-95.

30. Huh, J., Delorme, D.E., \& Reid, L. (2004). The third-person effect and its influence on behavioral outcomes in a product advertising context: The case of direct-to-consumer prescription drug advertising. Communication Research, 31, 568-599.

31. Innes, J.M., \& Zeitz, H. (1988). The public's view of the impact of the mass media: A test of the "third-person" effect. European Journal of Social Psychology, 18(5), 457-463.

32. Lasorsa, D.L. (1989). Real and perceived effects of "Amerika". Journalism Quarterly, 66, 373-378.

33. Lau, R.R., \& Pomper, G.M. (2001). Effects on negative campaigning on turnout in U.S. senate elections, 1988-1998. Journal of Politics, 63(3), 804-819.

34. Lee, B., \& Tamborini, R. (2005). Third-person effect and Internet pornography: the influence of collectivism and Internet self-efficacy. Journal of Communication, 55(2), 292-310.

35. Lev-On, A. (2016). The third-person effect on Facebook: The significance of perceived proficiency. Telematics and Informatics, http://dx.doi.org/10.1016/j.tele.2016. 07.002 .

36. Li, X. (2008). Third Person effect, optimistic bias, and sufficiency resource in internet use. Journal of Communication, 58(3), 568-587.

37. Liu, X., \& Lo, V.H. (2014). Media exposure, perceived personal impact, and thirdperson effect. Media Psychology, 17(4), 378-396.

38. Lo, V.H. \& Wei, R. (2002). Third-person effect, gender, and pornography on the Internet. Journal of Broadcasting \& Electronic Media, 46(1), 13-33.

39. Lo, V., Wei, R., \& Wu, H. (2010). Examining the first, second and third-person effects of internet pornography on taiwanese adolescents: Implications for the restriction of pornography. Asian Journal of Communication, 20(1), 90-103.

40. Mangold, W.G., \& Faulds, D.J. (2009). Social media: the new hybrid element of the promotion mix. Business Horizons, 52(4), 357-365. 
41. McLeod, D.M., Detenber, B.H. \& Eveland, W.P., Jr. (2001). Behind the thirdperson effect: Differentiating perceptual processes for self and others. Journal of Communication, 51(4), 678-695.

42. McLeod, D.M., Eveland, W.P., Jr., \& Nathanson, A.I. (1997). Support for censorship of violent and misogynic rap lyrics: An analysis of the third-person effect. Communication Research, 24(2), 153-174.

43. Meirick, P. (2005). Rethinking the target corollary: The effects of social distance, perceived exposure, and perceived predispositions on first person and third-person perceptions. Communication Research, 32, 822-843.

44. Nelson, T.E., Clawson, R.A., \& Oxley, Z.M. (1997). Media framing of a civil liberties conflict and its effect on tolerance. American Political Science Review, 91, 567-583.

45. Neuwirth, K., Frederick, E., \& Mayo, C. (2002). Person-effects and heuristic-systematic processing. Communication Research, 29, 320-359.

46. Park, H.S., \& Salmon, C.T. (2005). A test of the third-person effect in public relations: Application of social comparison theory. Journalism \& Mass Communication Quarterly, 82(1), 25-43.

47. Paul, B.M., Salwen, M.B., \& Dupagne, M. (2000). The third-person effect: A metaanalysis of the perceptual component. Mass Communication and Society, 3, 57-85.

48. Peiser, W., \& Peter, J. (2000). Third-person perception of television-viewing behavior. Journal of Communication, 50(1), 25-45.

49. Perloff, R.M. (2002). The third-person effect. In: Bryant, J., Zillmann, D. (Eds.), Media Effects: Advances in Theory and Research (pp. 489-506), Mahwah, NJ: Lawrence Erlbaum.

50. Perloff, R.M. (1993). Third-person effect research 1983-1992: A review and synthesis. International Journal of Public Opinion Research, 5, 167-184.

51. Perloff, R.M. (1989). Ego-involvement and the third-person effect of televised news coverage. Communication Research, 16, 236-262.

52. Price, V., Huang, L.N., \& Tewksbury, D. (1997). Third-person effects of news coverage: Orientations toward media. Journalism \& Mass Communication Quarterly, 74(3), 525-540.

53. Price, V., \& Tewksbury, D. (1996). Measuring the third-person effect of news: The impact of question order, contrast and knowledge. International Journal of Public Opinion Research, 8, 120-141.

54. Reid, S.A. \& Hogg, M.A. (2005). A Self-Categorization Explanation for the ThirdPerson Effect. Human Communication Research, 31(1), 129-161.

55. Rojas, H., Shah, D., \& Faber, R. (1996). For the good of others: Censorship and the third-person effect. International Journal of Public Opinion Research, 8, 163-186.

56. Ross, C., Orr, E., Sisic, M., Arseneault, J.M., Simmering, M.G., \& Orr, R. (2009). Personality and motivations associated with Facebook use. Computers in Human Behavior, 25(2), 578-586. 
57. Salwen, M.B., \& Dupagne, M. (1999). The third-person effect: Perceptions of the media's influence and immoral consequences. Communication Research, 26(5), 523-550.

58. Salwen, M.B., \& Driscoll, P.D. (1997). Consequences of third-person perception in support of press restrictions in the O.J. Simpson trial. Journal of Communication, 47(2), 60-78.

59. Scharrer, E. (2002). Third-person perception and television violence: The role of out-group stereotyping in perceptions of susceptibility to effects. Communication Research, 29, 681-704.

60. Scheier, M.F., Carver, C.S., \& Bridges, M.W. (1994).Distinguishing optimism from neuroticism (and trait anxiety, self-mastery, and self-esteem): A re-evaluation of the Life Orientation Test. Journal of Personality and Social Psychology, 67, 10631078.

61. Schweisberger, V., Billinson, J., \& Chock, T.M. (2014). Facebook, the Third-Person effect, and the differential impact hypothesis. Journal of Computer Mediated Communication, 19(3), 403-413.

62. Scharrer, E., \& Leone, R. (2008). First Person shooters and the Third Person effect. Human Communication Research, 34(2), 210-233.

63. Shah, D.V., Faber, R.J., \& Youn, S. (1999). Susceptibility and severity: Perceptual dimensions underlying the third-person effect. Communication Research, 26, 240-267.

64. Shen, L., Palmer, J., Mercer Kollar, L.M., \& Comer, S. (2015). A Social Comparison Explanation for the Third Person Perception. Communication Research, 42(2), 260280.

65. Stöber, J. (2001). The Social Desirability Scale-17 (SDS-17): Convergent validity, discriminant validity, and relationship with age. European Journal of Psychological Assessment, 17, 222-232.

66. Sun, Y., Shen, L., \& Pan, Z. (2008). On the behavioral component of the third-person effect. Communication Research, 35(2), 257-278.

67. Tsay-Vogel, M. (2016). Me versus them: Third-person effects among Facebook users. New Media \& Society, 18(9), 1956-1972.

68. Wan, F., \& Youn, S. (2004). Motivations to regulate online gambling and violent game sites: An account of the third-person effect. Journal of Interactive Advertising, 5(1), 46-59.

69. Wei, R., Lo, V-H. \& Lu, H-Y. (2007). Reconsidering the Relationship Between the Third-Person Perception and Optimistic Bias. Communication Research, 34(6), 665684.

70. White, H.A., \& Dillon, J.F. (2000). Knowledge about others' reaction to a public service announcement: The impact of self-persuasion and third-person perception. Journalism \& Mass Communication Quarterly, 77, 788-803.

71. White, H.A. (1997). Considering interacting factors in the third-person effect: Argument strength and social distance. Journalism and Mass Communication Quarterly, 74(3), 557-564. 
72. Zhong, Z.J., 2009. Third-person perceptions and online games: a comparison of perceived antisocial and prosocial game effects. Journal of Computer Mediated Communication, 14(2), 286-306. 